\title{
Benthic $\mathrm{NH}_{4}^{+}$and $\mathrm{NO}_{3}^{-}$flux following sedimentation of a spring phytoplankton bloom in Aarhus Bight, Denmark
}

\author{
Mikael Hjorth Jensen, Erik Lomstein*, Jan Sørensen** \\ Department of Ecology and Genetics, University of Aarhus, Ny Munkegade, DK-8000 Aarhus C, Denmark
}

\begin{abstract}
A seasonal study of $\mathrm{NH}_{4}^{+}$and $\mathrm{NO}_{3}^{-}$fluxes and concentrations at the sediment-water interface was carried out at a $15 \mathrm{~m}$ deep station in Aarhus Bight, Denmark. In winter, $\mathrm{NH}_{4}^{+}$and $\mathrm{NO}_{3}^{-}$ were released from the sediment at comparable rates $\left(0.20\right.$ to $\left.0.40 \mathrm{mmol} \mathrm{N} \mathrm{m}^{-2} \mathrm{~d}^{-1}\right)$. A phytoplankton bloom developed rapidly in early spring. Immediately after mass sedimentation of diatoms, the sediment transiently released $\mathrm{NH}_{4}^{+}$at a high rate (up to $1.5 \mathrm{mmol} \mathrm{N} \mathrm{m}{ }^{-2} \mathrm{~d}^{-1}$ ) and a dramatic change to a $\mathrm{NO}_{3}^{-}$uptake was observed (flux ca $-0.80 \mathrm{mmol} \mathrm{N} \mathrm{m} \mathrm{N}^{-2} \mathrm{~d}^{-1}$ ). Subsequently both the $\mathrm{NH}_{4}^{-}$release and $\mathrm{NO}_{3}^{-}$ uptake decreased (summer fluxes ca 0.35 and $-0.15 \mathrm{mmol} \mathrm{N} \mathrm{m} \mathrm{m}^{-2} \mathrm{~d}^{-1}$, respectively). From late summer, $\mathrm{NO}_{3}^{-}$was again released from the sediment ( $\mathrm{ca} 0.30 \mathrm{mmol} \mathrm{N} \mathrm{m} \mathrm{N}^{-2} \mathrm{~d}^{-1}$ ) and a second, weaker maximum of $\mathrm{NH}_{4}^{+}$release (ca $0.70 \mathrm{mmol} \mathrm{N} \mathrm{m} \mathrm{m}^{-2} \mathrm{~d}^{-1}$ ) was observed in fall. Seasonal variation of $\mathrm{NH}_{4}^{+}$and $\mathrm{NO}_{3}^{-}$ concentrations at the sediment surface (upper $2 \mathrm{~mm}$ ) and in the bottom water agreed well with observed flux patterns. The high $\mathrm{NH}_{4}^{+}$release and $\mathrm{NO}_{3}^{-}$uptake immediately after spring bloom sedimentation indicated rapid increases of mineralization and denitrification. Sediment nitrification seemed to be inhibited, however, probably because the $\mathrm{O}_{2}$ penetration depth was reduced after sedimentation. Uptake of bottom water $\mathrm{NO}_{3}$ rather than nitrification therefore seemed to support the denitrification maximum. Even when calculated for a whole year, about $50 \%$ of the $\mathrm{NO}_{3}^{-}$consumed during denitrification was supplied from the bottom water. Annual nitrogen budgets also indicated that denitrification accounted for $25 \%$ of the total inorganic nitrogen release from the sediment.
\end{abstract}

\section{INTRODUCTION}

Nitrogen is generally considered to limit primary production in coastal waters (Ryther \& Dunstan 1971), although the subordinate role of phosphorus has recently been discussed (Hecky \& Kilham 1988, Howarth 1988). Of major importance in controlling the concentrations of inorganic nitrogen species in shallow waters is their rate of exchange across the sedimentwater interface (i.e. benthic fluxes). Release of $\mathrm{NO}_{3}^{-}$and $\mathrm{NH}_{4}^{+}$from sediments can thus potentially supply from 30 to more than $100 \%$ of the annual nitrogen require-

\footnotetext{
- Present address: Department of Forage Crops, Danish Research Service for Plant and Soil Science, Foulum, DK8830 Tjele, Denmark

- Addressee for correspondence; present address: Department of Microbiology, Royal Veterinary and Agricultural University, Rolighedsvej 21, DK-1958 Frederiksberg C, Denmark
}

ment for primary producers in coastal areas (Blackburn \& Henriksen 1983).

Numerous investigations have dealt with benthic nitrogenous nutrient exchange in various estuarine and coastal sediments; see e.g. reviews by Klump \& Martens (1983) and Seitzinger (1988). The multitude of temporal and regional patterns reported indicate a complex relationship between various physico-chemical and biological control factors. Benthic nutrient exchange is largely determined by the rate of detritus sedimentation and decomposition in the sediment and the rate at which the nutrients are transported to or from the overlying water by diffusion and bioturbating infauna (e.g. Goldhaber et al. 1977). Thus, in addition to being important in nitrogen recycling, the benthic flux can also be an indicator of the actual processes involved in sediment nitrogen turnover (Hammond et al. 1985). For instance, interactions between microbial mineralization of organic nitrogen $\left(\mathrm{NH}_{4}^{+}\right.$production), nitrification (oxidation of $\mathrm{NH}_{4}^{+}$to $\mathrm{NO}_{3}^{-}$) and $\mathrm{NO}_{3}^{-}$reduc- 
tion, e.g. denitrification (reduction of $\mathrm{NO}_{3}^{-}$to gaseous $\mathrm{N}_{2} \mathrm{O}$ and $\mathrm{N}_{2}$ ), might be inferred from net benthic fluxes of $\mathrm{NH}_{4}^{+}$and $\mathrm{NO}_{3}^{-}$. A complete assessment of a sediment nitrogen cycle has been possible when flux determinations have been related to direct measurements of microbial process activities (Blackburn \& Henriksen 1983).

The present investigation focuses on the annual pattern of benthic fluxes and interfacial concentration gradients of $\mathrm{NH}_{4}^{+}$and $\mathrm{NO}_{3}^{-}$in a coastal bay area characterized by a massive sedimentation of the spring phytoplankton bloom. Sampling was carried out at a site where denitrification was recently found to change dramatically after the rapid sedimentation in spring (Jensen et al. 1988). The inorganic nitrogen fluxes were compared to the previously observed denitrification pattern on a seasonal and annual scale.

\section{MATERIALS AND METHODS}

Study area. The investigation was carried out in Aarhus Bight, Denmark, a $320 \mathrm{~km}^{2}$ embayment in the southwestern Kattegat. The water column of the Kattegat is stratified due to the outflow of low-salinity $(<10 \%)$ Baltic water from the south and an inflow of high-salinity $(>30 \%$ ) Skagerrak water from the north; the mean depth of the halocline is $15 \mathrm{~m}$ (Andersson \& Rydberg 1988). In the Aarhus Bight the water depth is about $15 \mathrm{~m}$ and the stratification periods are here interrupted by periods of mixing once or twice a year (Jensen et al. 1988).

Annual primary production in the Kattegat (above $100 \mathrm{~g} \mathrm{C} \mathrm{m}^{-2} \mathrm{yr}^{-1}$ in the Aarhus Bight) seems to be limited by nitrogen (Ertebjerg et al. 1981). The spring bloom develops in late winter (February-March) and rapidly depletes nutrient pools in the surface water. Due to the shallow water and the absence of grazing zooplankton at this time, a major portion of the algae reaches the sea floor undecomposed (Smetacek 1985, Jensen et al. 1988). The major sedimentation event typically occurs within a month, and less sedimentation may be found during summer (Smetacek 1980, Jensen et al. 1988).

The eutrophication of the Kattegat has become evident during the last decade. Using the extensive set of water column data available from various parts of the Kattegat, Andersson \& Rydberg (1988) found a general increase of particulate and dissolved nitrogen pools and a decrease of the $\mathrm{O}_{2}$ concentration in the Kattegat deep water; from the data they estimated that $\mathrm{O}_{2}$ consumption had increased by $50 \%$ between 1971 and 1982. In the Aarhus Bight, both the frequency and duration of $\mathrm{O}_{2}$ deficiency periods have increased during the last $20 \mathrm{yr}$ (Fallesen 1988).
For the present investigation (June 1987 to December 1988), a silty-mud locality was chosen in the central part of Aarhus Bight at a water depth of $15 \mathrm{~m}$. The sediment porosity in the upper $2 \mathrm{~mm}$ was 0.89; further description of the site, Stn 16, may be found in Jensen et al. (1988). The sediment was poorly inhabited by macrofauna during the investigation period. However, large specimens of polychaetes Nephtys spp. and bivalves Abra alba and Macoma calcarea were occasionally observed.

Sampling. Water and sediment were sampled at intervals of $5 \mathrm{~d}$ to 2 mo with intensive sampling in the spring of 1988, before and after sedimentation of the phytoplankton bloom.

Temperature, salinity, and concentrations of $\mathrm{O}_{2}, \mathrm{NH}_{4}^{+}$ and $\mathrm{NO}_{3}^{-}$(note: $\mathrm{NO}_{2}^{-}$concentrations were always very low in both water and sediment and are included in the $\mathrm{NO}_{3}^{-}$data) were determined in samples of surface water ( $2 \mathrm{~m}$ below the surface) and bottom water $(0.5 \mathrm{~m}$ above the sediment). Samples for determination of $\mathrm{O}_{2}$ concentrations were taken in $25 \mathrm{ml}$ Winkler bottles. Samples for nutrient analysis were stored frozen at $-20^{\circ} \mathrm{C}$ in $25 \mathrm{ml}$ polyethylene vials containing $50 \mathrm{ul}$ of chloroform.

Sediment was collected with a 'Haps' bottom corer (Kanneworff \& Nicolaisen 1973) taking $12.5 \mathrm{~cm}$ (i.d.) cores of the sediment. From the main 'Haps' core, smaller subcores were taken into $3.6 \mathrm{~cm}$ (i.d.) wide and $12 \mathrm{~cm}$ long acrylic tubes for determinations of in situ $\mathrm{NH}_{4}^{+}$and $\mathrm{NO}_{3}^{-}$fluxes and concentrations of pore water $\mathrm{NH}_{4}^{+}$and $\mathrm{NO}_{3}^{-}$. All cores were carefully inspected and only those with an undisturbed sediment-water interface were used. Measurements of fluxes and concentration profiles were initiated in the laboratory within a few hours of sampling.

In situ concentrations of $\mathrm{NH}_{4}^{+}$and $\mathrm{NO}_{3}^{-}$in the pore water (triplicate cores) were determined in the upper $2 \mathrm{~mm}$ section of the sediment; the sample was immediately centrifuged $(2900 \times \mathrm{g}, 5 \mathrm{~min})$ and the supernatant frozen at $-20^{\circ} \mathrm{C}$ for later analysis. Further details are given in Lomstein et al. (1990), a parallel seasonal investigation of in situ profiles of both dissolved and bound $\mathrm{NH}_{4}^{+}$and $\mathrm{NO}_{3}^{-}$pools in the 0 to $4 \mathrm{~cm}$ depth horizon at Stn 16.

Inorganic $\mathbf{N}$ fluxes. From 6 to 8 cores were collected to measure the sediment-water fluxes of $\mathrm{NH}_{4}^{+}$and $\mathrm{NO}_{3}^{-}$ on each sampling event. The sediment was first adjusted in height so that the acrylic tubes contained about $5 \mathrm{~cm}$ of sediment core overlain by $7 \mathrm{~cm}$ of water (corresponding to about $70 \mathrm{ml}$ ). The water phase was then discarded (except for a few $\mathrm{ml}$ to avoid disturbance of the sediment-water interface) and carefully replaced by fresh bottom water collected on the same day. A $10 \mathrm{ml}$ sample from the water overlying each core was saved for determination of initial concentrations of $\mathrm{NH}_{4}^{+}$and $\mathrm{NO}_{3}^{-}$. The cores were then completely filled 
with bottom water, capped and incubated in the dark at in situ temperature. The caps were equipped with small stirring bars to mix the water phase. Incubation time varied from less than $1 \mathrm{~h}$ to about $4 \mathrm{~h}$. Another $10 \mathrm{ml}$ sample from the water gave the final concentrations of $\mathrm{NH}_{4}^{+}$and $\mathrm{NO}_{3}^{-}$. After incubation the actual height (volume) of the water phase was noted. The incubated cores were sectioned for a determination of $\mathrm{NH}_{4}^{+}$and $\mathrm{NO}_{3}^{-}$in the pore water at 0 to $2 \mathrm{~mm}$ depth as described above. No build-up or depletion of either $\mathrm{NH}_{4}^{+}$or $\mathrm{NO}_{3}^{-}$in the upper $2 \mathrm{~mm}$ of pore water occurred during incubation as judged from the similar concentrations measured before and after an incubation.

During the incubation, $2 \mathrm{ml}$ water samples were taken frequently (2 or 3 times) from the cores and replaced with $2 \mathrm{ml}$ of bottom water; these samples served for detection of changes in flux rates. We observed only constant fluxes of $\mathrm{NH}_{4}^{+}$and $\mathrm{NO}_{3}^{-}$during the incubations as judged from linear increases or decreases in concentration over time. Occasionally, the $\mathrm{O}_{2}$ concentration in the water phase was measured immediately after capping and again at the end of incubation. Initial $\mathrm{O}_{2}$ concentrations in the cores were close to those measured in the bottom water and the concentrations at the end of the incubations indicated that less than $30 \%$ of the $\mathrm{O}_{2}$ initially present was consumed.

The sediment was finally sieved through a $1 \mathrm{~mm}$ mesh to look for larger macrofauna. Data recorded from such cores were discarded; only few, i.e. 1 or most often none, of the cores were discarded from each incubation series. Flux rates and concentrations are presented as means of 5 to 8 incubated cores. The present study does not include the impact of macrofauna on benthic nitrogen transformations and fluxes.

Sample analyses. Salinity was measured potentiometrically (Conductivity Meter CDM 3, Radiometer, Denmark) and dissolved $\mathrm{O}_{2}$ concentrations were measured by Winkler titration (Strickland \& Parsons 1972). Nutrient concentrations in the various samples were determined by the standard autoanalyzer methods of Solorzano (1969) for $\mathrm{NH}_{4}^{+}$and Armstrong et al. (1967) for $\mathrm{NO}_{3}^{-}$plus $\mathrm{NO}_{2}^{-}$.

\section{RESULTS}

On Figs. 1 to 3, shaded areas indicate the duration of the spring phytoplankton bloom based on the $\mathrm{NO}_{3}^{-}$concentration pattern in the surface water. In 1988, $\mathrm{NO}_{3}^{-}$consumption began in early March and continued through depletion in early April (Fig. 2B), when also a complete change of the surface sediment was visually observed. Extensive phytoplankton sedimentation had clearly occurred just prior to the sampling event in early April.

\section{Hydrographics}

A seasonal temperature minimum of $2{ }^{\circ} \mathrm{C}$ in the bottom water was recorded during March (Fig. 1A). In $2 \mathrm{wk}$, the temperature rose quickly to $5^{\circ} \mathrm{C}$ and a strong halocline developed (Fig, 1B), indicating an intrusion of 'new' water into the bight which coincided with the sedimentation of the spring phytoplankton bloom. Thus, a decrease from 25 to $18 \%$ and an increase from 27 to $33.5 \%$ were recorded for the surface and bottom water salinities, respectively; the latter value shows that the intruding bottom water was Kattegat deep water (Andersson \& Rydberg 1988). The marked saline stratification continued and the thermal stratification intensified in the following months. After a period with intermittent mixing, the water column finally became thoroughly mixed during October. The major hydrographic events in early spring and fall

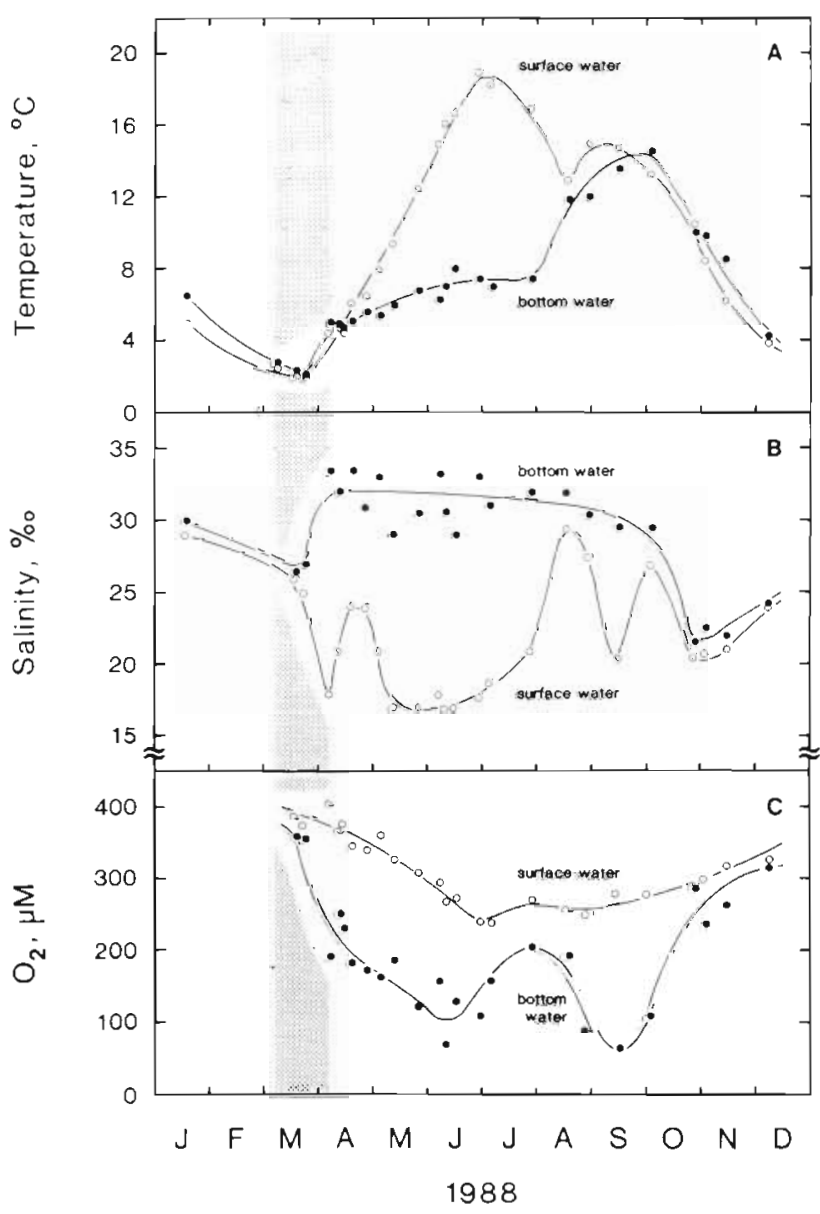

Fig. 1. Water column characteristics from Aarhus Bight (1988): (A) temperature; (B) salinity, and (C) $\mathrm{O}_{2}$ concentration. ( ) Surface water; $(\bullet)$ bottom water Shaded area indicates the production and sedimentation period of the spring bloom (see text) 
were also reflected in the concentration patterns of $\mathrm{O}_{2}$ $\mathrm{NO}_{3}^{-}$and $\mathrm{NH}_{4}^{+}$.

The bottom water $\mathrm{O}_{2}$ concentration decreased from $360 \mu \mathrm{M}$ (complete saturation) to $190 \mu \mathrm{M} \mathrm{O} \mathrm{O}_{2}(60 \%$ saturation) between late March and early April (Fig. 1C), when the saline bottom water intruded the bight. The bottom water remained partially deficient in $\mathrm{O}_{2}$ (60 to $250 \mu \mathrm{M} \mathrm{O}_{2}$ or 22 to $77 \%$ saturation) until the water column was mixed during October.

\section{$\mathrm{NH}_{4}^{+}$and $\mathrm{NO}_{3}^{-}$in water and suriace sediment}

The high winter concentrations of $\mathrm{NH}_{4}^{+}$and $\mathrm{NO}_{3}^{-}$ (maxima of 3 and 10 to $15 \mu \mathrm{M}$, respectively), typical for the relatively well-mixed and oxygenated water column, are evident from Fig. 2. The initiation of the spring bloom resulted in a rapid nutrient consumption, and by early April both $\mathrm{NH}_{4}^{+}$and $\mathrm{NO}_{3}^{-}$were almost depleted $(<1 \mu \mathrm{M})$ in the surface water. The Kattegat deep water intruding the bight was rich in $\mathrm{NO}_{3}^{-}$in addition to being low in oxygen: $\mathrm{NO}_{3}^{-}$in bottom water thus returned to a high level in early April $(14.7 \mu \mathrm{M})$ coinciding with the sedimentation event. Both the $\mathrm{NO}_{3}^{-}$ concentrations ( 8 to $10 \mu \mathrm{M}$ ) and $\mathrm{NH}_{4}^{+}$concentrations ( 3 to $5 \mu \mathrm{M}$ ) were relatively high in the bottom water during the marked summer stratification. As destratifi- cation was initiated in August, the water column became depleted of nutrients. The bottom water was occasionally high in $\mathrm{NH}_{4}^{+}$during the early fall. Nitrate reappeared in the water column after the mixing events during October.

The concentrations of dissolved $\mathrm{NH}_{4}^{+}$and $\mathrm{NO}_{3}^{-}$in the upper sediment layer ( 0 to $2 \mathrm{~mm}$ ) varied considerably during the season (Figs. 2A, B). Sedimentation of the spring bloom induced a significant change in the pool of dissolved $\mathrm{NH}_{4}^{+}$, observed as an increase from ca $10 \mu \mathrm{M}$ to above $40 \mu \mathrm{M}$ between March and April (Fig. 2A). A steep decrease was observed during May and apart from a weaker peak in early October (ca $30 \mu \mathrm{M}$ ), the concentration remained in the 10 to $20 \mu \mathrm{M}$ range during the rest of the year. The concentration of pore water $\mathrm{NO}_{3}^{-}$, which always peaked at 0 to $2 \mathrm{~mm}$ depth, increased from fall to winter and a maximum concentration of ca $25 \mu \mathrm{M}$ was found in March (Fig. 2B); during the rest of the year, the $\mathrm{NO}_{3}^{-}$concentration did not exceed $15 \mu \mathrm{M}$. Between spring bloom sedimentation and depletion of bottom water $\mathrm{NO}_{3}^{-}$ (April to July), the concentrations were generally higher in bottom water than in pore water, although within similar ranges ( 8 to $15 \mu \mathrm{M}$ and 6 to $12 \mu \mathrm{M}$. respectively). Lowest pore water concentrations, ca $5 \mu \mathrm{M}$, were found in the early fall (SeptemberOctober), when $\mathrm{NO}_{3}^{-}$was depleted in the bottom water.

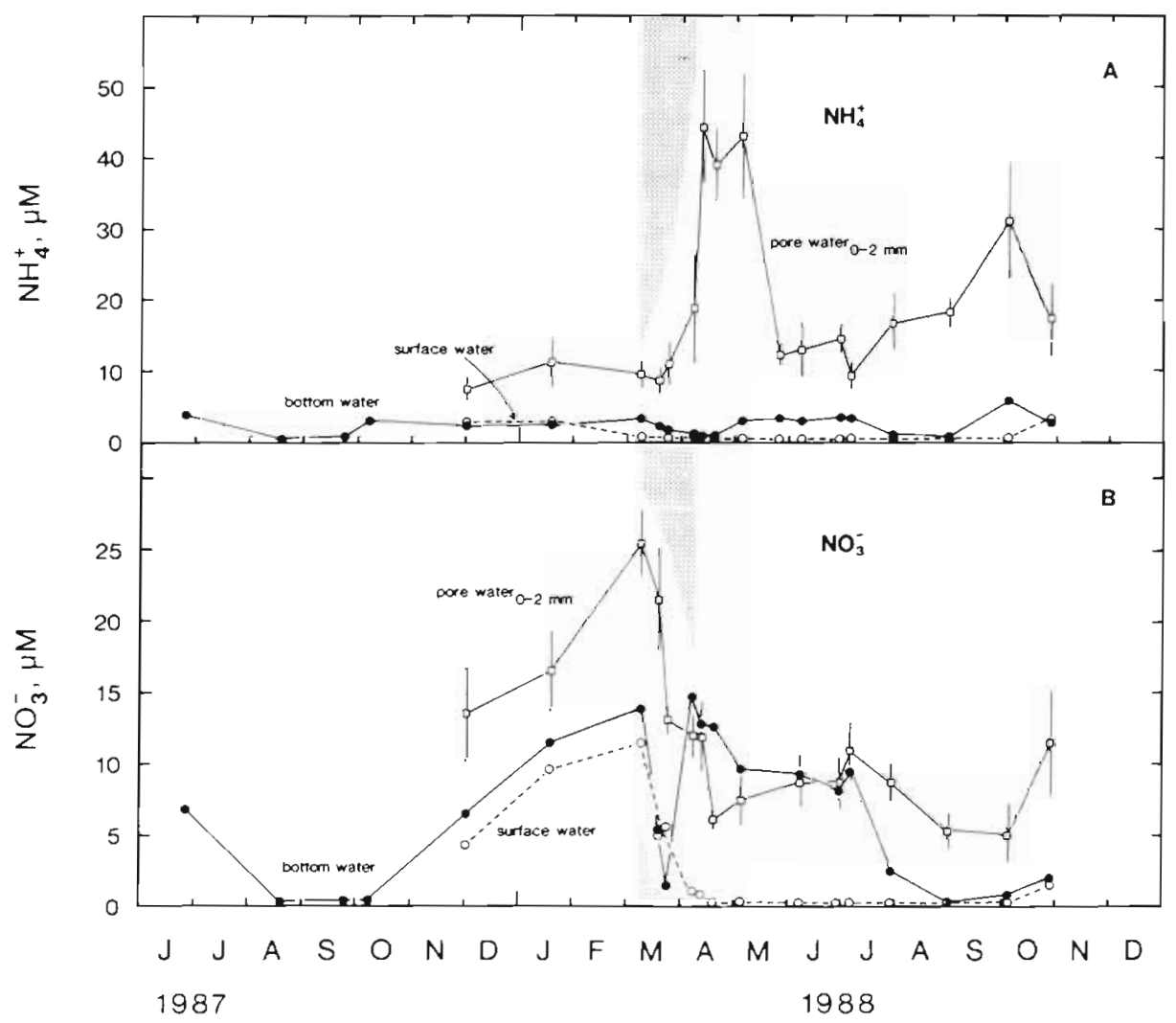

Fig. 2. Seasonal patterns of $(A)$ $\mathrm{NH}_{4}^{+}$and $(\mathrm{B}) \mathrm{NO}_{3}^{-}$concentrations in water and surface sediment at Stn 16 in Aarhus Bight (1987 to 1988). () Surface water; ( $\bullet$ bottom water; $(-)$ pore water at 0 to $2 \mathrm{~mm}$ depth imean and $\mathrm{SE}$ values indicated; $\mathrm{n}=5$ to 8 ). Shaded area as in Fig. 1 


\section{Fluxes of $\mathrm{NH}_{4}^{+}$and $\mathrm{NO}_{3}^{-}$}

Lowest $\mathrm{NH}_{4}^{+}$fluxes, ca $0.20 \mathrm{mmol} \mathrm{N} \mathrm{m}^{-2} \mathrm{~d}^{-1}$, were measured in March (Fig. 3A). A dramatic increase was observed following the spring bloom sedimentation and a seasonal maximum of $\mathrm{ca} 1.5 \mathrm{mmol} \mathrm{N} \mathrm{m}^{-2} \mathrm{~d}^{-1}$ was recorded in April. Shortly after, $\mathrm{NH}_{4}^{+}$release decreased abruptly and rates were only ca $0.35 \mathrm{mmol} \mathrm{N} \mathrm{m} \mathrm{N}^{-2} \mathrm{~d}^{-1}$ in May to July. In September-October they were somewhat higher, 0.60 to $0.70 \mathrm{mmol} \mathrm{N} \mathrm{m}^{-2} \mathrm{~d}^{-1}$. The highest fluxes coincided with the steepest interfacial $\mathrm{NH}_{4}^{+}$gradients and generally, the seasonal patterns of fluxes and concentration gradients corresponded remarkably well (Figs. 2A and 3A).

From late summer and throughout the winter (August to March), $\mathrm{NO}_{3}^{-}$was released from the sediment at rates between 0.10 and $0.35 \mathrm{mmol} \mathrm{N} \mathrm{m}^{-2} \mathrm{~d}^{-1}$ (Fig. 3B). A sudden change to a high uptake by the sediment was observed between late March and early April when the intrusion of $\mathrm{NO}_{3}^{-}$-rich bottom water and the bloom sedimentation took place, resulting in negative $\mathrm{NO}_{3}^{-}$ fluxes between -0.60 and $-0.80 \mathrm{mmol} \mathrm{N} \mathrm{m}^{-2} \mathrm{~d}^{-1}$. The uptake rate declined rapidly and the flux was only about $-0.15 \mathrm{mmol} \mathrm{N} \mathrm{m}^{-2} \mathrm{~d}^{-1}$ in May to July, when the bottom water still was rich in $\mathrm{NO}_{3}^{-}$. In the whole period from April to July, the rate of $\mathrm{NO}_{3}^{-}$uptake was apparently proportional to the $\mathrm{NO}_{3}^{-}$concentration in the bottom water $\left(\mathrm{r}^{2}=0.88, \mathrm{n}=8\right)$. As $\mathrm{NO}_{3}^{-}$disappeared from the bottom water in August, a net release of $\mathrm{NO}_{3}^{-}$was again recorded. The shifts in the direction of the $\mathrm{NO}_{3}^{-}$flux in early spring and late summer could generally be predicted from the changes in concentration gradients at the sediment-water interface (Figs. $2 \mathrm{~B}$ and $3 \mathrm{~B}$ ).

\section{DISCUSSION}

\section{Sedimentation and benthic metabolism during spring}

The spring bloom of primary production occurs in late winter/early spring when ambient light is sufficient and the water column is rich in nutrients. When
Fig. 3. Seasonal patterns of (A) $\mathrm{NH}_{4}^{+}$and (B) $\mathrm{NO}_{3}^{-}$fluxes (mean and SE values indicated; $n=5$ to 8 ) at Stn 16 in Aarhus Bight (1987 to 1988). Negative flux indicates uptake by the sediment. Shaded area as in Fig. 1

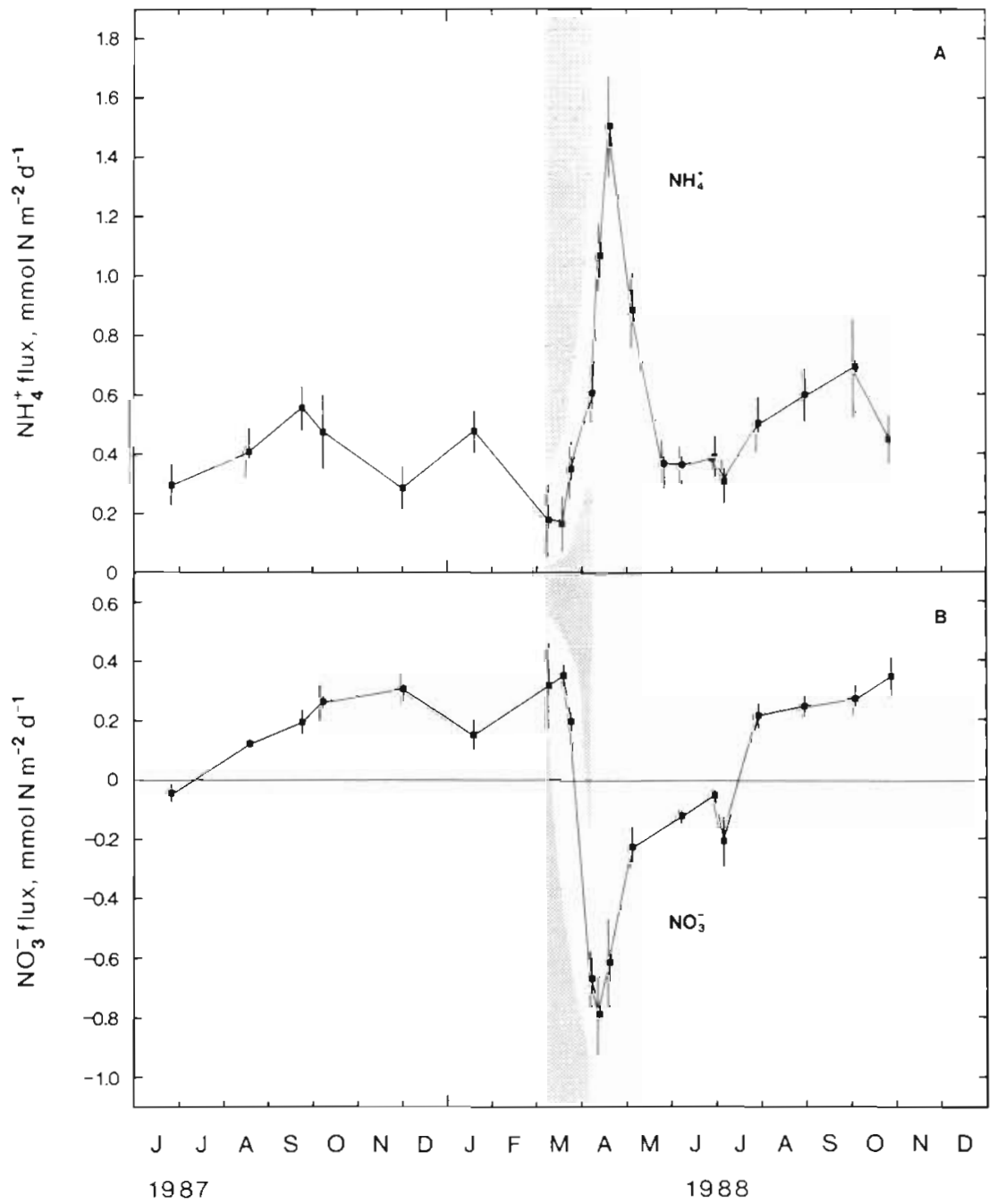


the nutrient stock in the surface water were depleted in early April, a brownish flocculent layer, 1 to $2 \mathrm{~mm}$ thick, containing an abundance of diatoms (notably Skeletonema costatum) was clearly visible on the sediment surface indicating that mass sedimentation had occurred within a $2 \mathrm{wk}$ period between sampling occasions in late March and early April. Although sedimentation probably continued on a smaller scale throughout April, the major sedimentation event gave a pulse input of organic matter to the sea floor.

Others have found that the rapid input of labile organic matter to the sea floor immediately triggers increased microbial activity at the sediment surface despite low temperatures in early spring (Graf 1987. Meyer-Reil 1987). One consequence of the sedimentation was a sudden decrease of the penetration depth of $\mathrm{O}_{2}$ in the sediment; while the oxic zone at $\mathrm{Stn} 16$ was ca $5 \mathrm{~mm}$ deep in late March, it was only $1.5 \mathrm{~mm}$ in early April (Rasmussen 1989). This was probably due to an increased $\mathrm{O}_{2}$ consumption immediately after sedimentation, although the decrease of the bottom water $\mathrm{O}_{2}$ content (Fig. 1C) also contributed to the lower $\mathrm{O}_{2}$ penetration. Enoksson (1987) similarly found a spontaneous doubling of the $\mathrm{O}_{2}$ consumption rate (mineralization rate) after undisturbed sediment cores were spiked with algal detritus.

After the sedimentation event, we frequently observed a dark-colored band of ca $1 \mathrm{~mm}$ thickness just below the flocculent diatom layer at the surface. The dark coloration was due to FeS precipitation and originated from $\mathrm{SO}_{4}^{2-}$ reduction immediately below the oxic zone (L. Moeslund pers. comm.). The sudden deposition of phytodetritus depleted $\mathrm{O}_{2}$ and apparently resulted in development of a very narrow $\mathrm{SO}_{4}^{2 \cdots}$ reduction zone which was clearly separated from the deeper, conventional $\mathrm{SO}_{4}^{2-}$ reduction zone. A similar surficial zone with $\mathrm{SO}_{4}^{2-}$ reduction (and low $\mathrm{O}_{2}$ penetration), related to accumulation of organic aggregates, has been demonstrated in a soft-bottom sediment in the Skagerrak (Sørensen \& Jorgensen 1987). Later in summer, the black zone was gradually displaced downwards in the sediment and was observed with much lower frequency in the cores; it completely disappeared in June-July

Both nitrification and denitrification might be affected by the transient appearance of a discrete, reduced layer in the surface sediment. Both the sediment $\mathrm{NO}_{3}^{-}$profiles showing a maximum at 0 to $2 \mathrm{~mm}$ depth and a depletion below $1 \mathrm{~cm}$ (Lomstein et al. 1990), and the $\mathrm{N}_{2} \mathrm{O}$ accumulations in depth-sectioned, $\mathrm{C}_{2} \mathrm{H}_{2}$-inhibited sediment from Stn 16 (Jensen et al. 1988), indicated that all nitrification and denitrification activity is located within the upper $1 \mathrm{~cm}$. The brownish surface floc as well as the dark band underneath had variable size and distribution on the sediment surface. and could in some cores be absent. Hammond et al. (1985) suggested that only certain areas (patches) of surface sediment may be sufficiently oxidized to favour nitrification, while others showing rapid $\mathrm{O}_{2}$ consumption may act as $\mathrm{NO}_{3}^{-}$sinks. This may also have been the case at $\operatorname{Stn} 16$ in the period following sedimentation, and Jensen et al. (1988) assigned a considerable core variability of denitrification rates to sediment heterogeneity.

\section{Seasonal variations of fluxes and concentrations of $\mathrm{NH}_{4}^{+}$and $\mathrm{NO}_{3}^{-}$}

During winter, the $\mathrm{O}_{2}$ penetration depth was at i.ts seasonal maximum (Rasmussen 1989) and the $\mathrm{NH}_{4}^{+}$flux and $\mathrm{NH}_{4}^{+}$concentrations in the pore water were relatively low. The organic matter at the sediment surface is probably relatively refractory and $\mathrm{N}$-deficient during winter (Blackburn 1987). A likely low $\mathrm{NH}_{4}^{+}$formation from mineralization was apparently met by relatively efficient $\mathrm{NH}_{4}^{+}$oxidation by nitrifying bacteria; hence, the $\mathrm{NH}_{4}^{+}$and $\mathrm{NO}_{3}^{-}$releases were in the same range 10.20 to $0.30 \mathrm{mmol} \mathrm{N} \mathrm{m}^{-2} \mathrm{~d}^{-1}$ \}. Marked $\mathrm{NO}_{3}^{-}$accumulation in the surface sediment and a release of $\mathrm{NO}_{3}^{-}$to the overlying water also indicated that nitrification was important during winter. Nedwell et al. (1983) suggested that sediment nitrification prevents a release of $\mathrm{NH}_{4}^{+}$from Baltic sediments during winter, and there, $\mathrm{NO}_{3}^{-}$ accounted for as much as $92 \%$ of the total $\mathrm{NH}_{4}^{+}$plus $\mathrm{NO}_{3}^{-}$flux. The low winter denitrification measured in the present sediment, ca $0.1 \mathrm{mmol} \mathrm{N} \mathrm{m}^{-2} \mathrm{~d}^{-1}$ (Jensen et al. 1988), must be supported by sediment nitrification and by the $\mathrm{NO}_{3}^{-}$pool in the bottom water when the latter was large. A net efflux of $\mathrm{NO}_{3}^{-}$due to nitrification in the surface sediment does not necessarily imply that denitrification is supported by nitrification alone unless $\mathrm{NO}_{3}^{-}$is absent from the overlying water (Christensen et al. in press).

Fluxes and concentrations of $\mathrm{NH}_{4}^{+}$and $\mathrm{NO}_{3}^{-}$changed dramatically after sedimentation of the spring bloom (Figs. 2 and 3). Such a distinct and rapid response in sediment metabolism occurring after a bloom sedimentation in a coastal area has, to our knowledge, not previously been reported from in situ measurements. The increases of both the pore water $\mathrm{NH}_{4}^{+}$concentration and the $\mathrm{NH}_{4}^{+}$flux were apparently due to the sudden increase in availability and rapid mineralization of a labile organic nitrogen pool. However, suppression of nitrification activity may also be important. The 7.5 -fold increase measured for the in situ $\mathrm{NH}_{4}^{-}$flux is in accordance with a 6 - to 10 -fold increase found in sediment core microcosms in which a sedimentation event was mimicked (Kelly \& Nixon 1984, Enoksson 1987). Garber (1984) similarly observed rapid release of 
${ }^{15} \mathrm{NH}_{4}^{+}$to pore water and overlying water after adding ${ }^{15} \mathrm{~N}$-labelled organic matter to the surface of undisturbed sediment. By comparing low and high additions of organic matter, Kelly \& Nixon (1984) found slowly and rapidly increasing $\mathrm{NH}_{4}^{+}$fluxes, respectively The steep increase of $\mathrm{NH}_{4}^{+}$release at Stn 16 indicated that the bloom sedimentation event was rapid, in accordance with our visual observation of a brown diatom layer being deposited on the sediment in less than 2 wk. During May, the $\mathrm{NH}_{4}^{+}$flux decreased to almost winter levels, corresponding with the decline to background levels within 1 to 2 mo observed in Kelly \& Nixon's (1984) microcosms. The rapid decline of the $\mathrm{NH}_{4}^{+}$release may represent exhaustion of the labile fraction of the detrital nitrogen pool.

The combination of bloom sedimentation and intrusion of $\mathrm{NO}_{3}^{-}$-rich bottom water was responsible for the rapid change from a modest release in winter to a high $\mathrm{NO}_{3}^{-}$uptake in early spring. At similar bottom water concentrations of $\mathrm{NO}_{3}^{-}$in early March and early April (13.9 and $14.7 \mu \mathrm{M}$, respectively), totally different fluxes were thus recorded $\left(0.30\right.$ and $-0.70 \mathrm{mmol} \mathrm{N} \mathrm{m}^{-2} \mathrm{~d}^{-1}$, respectively). This observation alone is sufficient to imply that the processes involved in $\mathrm{NO}_{3}^{-}$turnover changed dramatically after the sedimentation, and a marked stimulation of denitrification in early spring has in fact recently been found in Aarhus Bight sediments (Jensen et al. 1988); the denitrification rates at Stn 16 were similar, if not identical, to the present $\mathrm{NO}_{3}^{-}$ uptake rates both in April and May to July which suggests a low nitrification activity following sedimentation. Even though the onset of rapid mineralization and $\mathrm{NH}_{4}^{+}$release after deposition of the phytodetritus is expected to stimulate volume-specific nitrification (Kemp et al. 1982, Henriksen \& Kemp 1988), overall nitrification might in fact be suppressed because the $\mathrm{O}_{2}$ concentration and penetration depth decreased dramatically after bloom sedimentation. Nitrifiers compete poorly with heterotrophs at low $\mathrm{O}_{2}$ availability (Belser 1979), and Hansen et al. (1981) suggested the depth extension of the oxic zone to be a major controlling factor of nitrification in sediments. The transient decrease of nitrification activity following rapid spring bloom sedimentation was already suggested in our previous work (Jensen et al. 1988), and is strongly supported by the present observations of a change in the direction of the interfacial $\mathrm{NO}_{3}^{-}$gradient, a sudden change to a high sediment uptake of $\mathrm{NO}_{3}^{-}$, a significant $\mathrm{NH}_{4}^{+}$accumulation in the surface sediment and a highly increased $\mathrm{NH}_{4}^{+}$release. Comparable results were obtained by Enoksson (1987) from incubation of cores in a continuous flow-through system; firstly, the $\mathrm{NO}_{3}^{-}$ flux immediately changed direction from a release to a net uptake after algal cells were added to the sediment surface, and secondly, nitrification seemed to cease completely due to $\mathrm{O}_{2}$ limitation because the highly increased $\mathrm{NH}_{4}^{+}$flux equalled the calculated $\mathrm{NH}_{4}^{+}$production.

It seems likely that diffusion from the water phase was the predominant $\mathrm{NO}_{3}^{-}$source for denitrification from the onset of sedimentation until depletion of the bottom water $\mathrm{NO}_{3}^{-}$, since the $\mathrm{NO}_{3}^{-}$uptake rate was proportional to the $\mathrm{NO}_{3}^{-}$concentration in the bottom water during the whole period (April to July). If a partial or complete inhibition of nitrification took place, the spring maximum of denitrification may have been further facilitated by the reduced depth of the oxic surface zone. The thickness of the oxic zone (i.e. the diffusion barrier for $\mathrm{NO}_{3}^{-}$) is a major controlling factor for denitrification, when the $\mathrm{NO}_{3}^{-}$concentration is lower or equal to the $\mathrm{O}_{2}$ concentration in the overlying water (Nielsen et al. in press). The denitrification maximum in the spring could thus have been due to an increase of the diffusion supply of $\mathrm{NO}_{3}^{-}$occurring after the oxic surface zone became narrower, although a direct stimulation of the process by the input of labile organic substrate cannot be excluded.

The results suggest that denitrification was the predominant $\mathrm{NO}_{3}^{-}$-consuming process in the sediment. An algal uptake of $\mathrm{NO}_{3}^{-}$following the spring sedimentation at $\operatorname{Stn} 16$ was possible, however, since a fraction of the diatoms deposited in the early spring were viable (mainly Skeletonema costatum) and contained considerable amounts of intracellular (particulate) $\mathrm{NH}_{4}^{+}$and $\mathrm{NO}_{3}^{-}$(Lomstein et al. 1990). These intracellular pools persisted in the surface sediment throughout summer, and the deposited microalgae might have continued their assimilation of nutrients, taking up $\mathrm{NH}_{4}^{+}$and $\mathrm{NO}_{3}^{-}$ from the bottom water and pore water (Lomstein et al. 1990). Results from other light-limited Kattegat sediments at similar depth (Blackburn \& Henriksen 1983, Sundbäck \& Granéli 1988, Sundbäck \& Jönsson 1988) indicated that sufficient light prevails from early spring to late summer for microphytobenthic primary production by both pelagic and benthic species, and that $\mathrm{O}_{2}$ production and nutrient assimilation by the microalgae are presumably important for the direction and magnitude of the benthic inorganic nitrogen flux. Even though our flux measurements were performed in the dark, a possible microalgal assimilation of $\mathrm{NH}_{4}^{+}$and $\mathrm{NO}_{3}^{-}$might have continued during incubations (e.g. Andersen \& Kristensen 1988).

The variations of both $\mathrm{NH}_{4}^{+}$and $\mathrm{NO}_{3}^{-}$fluxes from August onwards were relatively small and showed no significant trends. There was perhaps a small, secondary maximum of $\mathrm{NH}_{4}^{+}$release $\left(0.60\right.$ to $0.70 \mathrm{mmol} \mathrm{N} \mathrm{m}{ }^{-2}$ $\left.\mathrm{d}^{-1}\right)$ at high temperatures during fall $\left(12\right.$ to $15^{\circ} \mathrm{C}$, September-October). Such maxima coinciding with seasonal temperature maxima have occasionally been reported (e.g. Nixon et al. 1976, Boynton et al. 1980, 
none of these studies were apparently based on frequent seasonal sampling, and specific temporal patterns of inorganic nitrogen flux and denitrification might have been overlooked. On the other hand, various characteristics of the Kattegat area such as the significant spring sedimentation and the strongly stratified water column with occasional intrusion of nutrient-rich bottom water may impede a direct comparison with many of the investigated areas cited by Seitzinger (1988). This study shows that there is no reason to expect a consistently strong nitrificationdenitrification coupling in highly fluctuating areas like Aarhus Bight.

Acknowledgements. We are indebted to Hans Jensen on board 'Genetica' for his assistance during sampling and to Dorthe Olsson and Karen Schacht Christiansen for skillfully performing the chemical analyses. We also thank $T$. Henry Blackburn and Erik Kristensen for valuable comments on an earlier version of the manuscript. This study was supported by the National Agency for Environmental Protection under the Danish Ministry of the Environment

\section{LITERATURE CITED}

Ertebjerg, G., Jacobsen, T., Gargas, E., Buch, E. (1981). The Belt project. Evaluation of the physical, chemical and biological measurements. The National Agency of Environmental Protection, Copenhagen, Denmark

Andersen, F. Ø., Kristensen, E. (1988). The influence of macrofauna on estuarine benthic community metabolism: a microcosm study. Mar. Biol. 99: 591-603

Andersson, L., Rydberg, L. (1988). Trends in nutrient and oxygen conditions within the Kattegat: effects of local nutrient supply. Estuar coast. Shelf Sci. 26: 559-579

Armstrong, F. A., Stearns, C. R., Strickland, J. D. (1967). The measurement of upwelling and subsequent biological processes by means of the Technicon Autoanalyzer and associated equipment. Deep Sea Res. 14: 381-389

Belser, L. W (1979). Population ecology of nitrifying bacteria Ann. Rev. Microbiol. 33: 309-333

Blackburn, T H. (1987). Microbial food webs in sediments. In Sleigh, M. A. (ed.) Microbes in the sea. Ellis Horwood Chichester, p. 39-58

Blackburn, T. H., Henriksen, K. (1983). Nitrogen cycling in different types of sediment from Danish waters. Limnol Oceanogr. 28: 477-493

Boucher, G., Boucher-Rodoni, R. (1988). In situ measurement of respiratory metabolism and nitrogen fluxes at the interface of oyster beds. Mar. Ecol. Prog. Ser. 44: 229-238

Boynton, W. R., Kemp, W. M. (1985). Nutrient regeneration and oxygen consumption by sediments along an estuarine salinity gradient. Mar. Ecol. Prog. Ser. 23: 45-55

Boynton, W. R., Kemp, W. M., Osborne, C. G. (1980). Nutrient fluxes across the sediment-water interface in the turbid zone of a coastal plain estuary. In: Kennedy, V. S. (ed.) Estuarine perspectives. Academic Press, New York, p. 93-109

Christensen, P. B., Nielsen, L. P., Revsbech, N. P., Sørensen, J (1990). Denitrification in nitrate-rich streams: diurnal and seasonal variation related to benthic oxygen metabolism. Limnol. Oceanogr. (in press)
Enoksson, V (1987). Nitrogen flux between sediment and water and its regulatory factors in coastal areas. Ph.D. thesis, Univ. Göteburg, Sweden

Fallesen, G. (1988). Oxygen deficiency, death of fish and phytoplankton blooms in marine areas within the county of Aarhus. Techn. Rep., Dept. Environ., County of Aarhus. Denmark

Garber, J. H. (1984). ${ }^{15} \mathrm{~N}$ study of the short-term fate of particulate organic nitrogen at the surface of coastal marine sediments. Mar. Ecol. Prog. Ser 16: 89-104

Goldhaber, M. B., Aller, R. C., Cochran, J. K., Rosenfeld, J. K. Martens, C. S., Berner, R. A. (1977). Sulfate reduction, diffusion and bioturbation in Long Island Sound sediments: Report of the FOAM group. Am. J. Sci. 277: 193-237

Graf, G. (1987). Benthic response to the annual sedimentation patterns. In: Rumohr, J., Walger, E., Zeitzschel, B. (eds.) Lecture notes on coastal and estuarine studies, Vol. 13. Seawater-sediment interactions in coastal waters. An interdisciplinary approach. Springer-Verlag, New York, p. $84-92$

Hammond, D. E., Fuller, C., Harmon, D., Hartman, B. Korosec, M., Miller, L. G., Rea, R., Warren, S., Berelson, W., Hager, S. W (1985). Benthic fluxes in San Francisco Bay. Hydrobiologia 129: 69-90

Hansen, J. I., Henriksen, K., Blackburn, T H. (1981). Seasonal distribution of nitrifying bacteria and rates of nitrification in coastal marine sediments. Microb. Ecol. 7. 297-304

Hecky, R. E., Kilham, P. (1988). Nutrient limitation of phytoplankton in freshwater and marine sediments: a review of recent evidence on the effects of enrichment. In: Nixon, S. W. (ed.) Comparative ecology of fresh water and coastal marine systems. Limnol. Oceanogr 33, spec. publ. no. 4 $796-822$

Henriksen, K., Kemp, W. M. (1988). Nitrification in estuarine and coastal marine sediments. In: Blackburn, T. H., Sørensen, J. (eds.) Nitrogen cycling in coastal marine environments. John Wiley \& Sons, Chichester, p. 207-249

Horrigan, S. G., Capone, D. G. (1985). Rates of nitrification and nitrate reduction in nearshore marine sediments at near ambient substrate concentrations. Mar Chem. 16 $317-327$

Howarth, R. W (1988). Nutrient limitation of net primary production in marine ecosystems. Ann. Rev. Ecol. 19 89-110

Jenkins, M. C., Kemp, W. M. (1984). The coupling of nitrification and denitrification in two estuarine sediments. Limnol. Oceanogr. 29: 609-619

Jensen, M. H., Andersen, T. K., Sorensen, J. (1988). Denitrification in coastal bay sediment: regional and seasonal variation in Aarhus Bight, Denmark. Mar. Ecol. Prog. Ser 48: $155-162$

Kanneworff, E., Nicolaisen, W. (1973). The 'Haps', a frame supported bottom corer. Ophelia 10: 119-128

Kelly, J. R., Nixon, S. W. (1984). Experimental studies of the effect of organic deposition on the metabolism of a coastal marine bottom community. Mar. Ecol. Prog. Ser. 17: 157-169

Kemp, W M., Wetzel, R. L., Boynton, W. R., D'Elia, C. F. Stevenson, J. C. (1982). Nitrogen cycling and estuarine interfaces: some concepts and research directions. In: Kennedy, V. S. (ed.) Estuarine comparisons. Academic Press, New York, p. 209-230

Klump, J. V., Martens, C. S. (1971). Biogeochemical cycling in an organic rich coastal marine basin. II. Nutrient sedimentwater exchange processes. Geochim. cosmochim. Acta. 45 $101-121$ 
Klump, J. V., Martens, C. S. (1983). Benthic nitrogen regeneration. In: Carpenter, E. J., Capone, D. G. (eds.) Nitrogen in the marine environment. Academic Press, New York, p. 411-457

Lomstein, E., Jensen, M. H., Sørensen, J. (1990). Intracellular $\mathrm{NH}_{4}^{+}$and $\mathrm{NO}_{3}^{-}$pools associated with deposited phytoplankton in a marine sediment (Aarhus Bight, Denmark). Mar Ecol. Prog. Ser. 97-105

Meyer-Reil, L.-A. (1987). Seasonal and spatial distribution of extracellular enzymatic activities and microbial incorporation of dissolved organic substrates in marine sediments. Appl, environ. Microbiol. 53: 1748-1755

Nedwell, D. B., Hall, S.-E., Andersson, A., Hagström, A. F., Lindstrom, E. B. (1983). Seasonal changes in the distribution and exchange of inorganic nitrogen between sediment and water in the northern Baltic (Gulf of Bothnia). Estuar. coast. Shelf Sci. 17: 169-179

Nielsen, L. P., Christensen, P. B., Revsbech, N. P., Sørensen, J. (in press). Denitrification and photosynthesis in stream sediment studied with microsensor and whole core techniques. Limnol. Oceanogr.

Nishio, T., Koike, I., Hattori, A. (1983). Estimates of denitrification and nitrification in coastal and estuarine sediments. Appl. environ. Microbiol. 45: 444-450

Nixon, S. W., Oviatt, C. A., Hale, S. S. (1976). Nitrogen regeneration and the metabolism of coastal marine bottom communities. In: Anderson, J. M., MacFadyen, A. (eds.) The role of terrestrial and aquatic organisms in decomposition processes. Blackwell Sci. Publ., Oxford, p. 269-283

Nowicki, B. L., Nixon, S. W. (1985). Benthic nutrient remineralization in a coastal lagoon ecosystem. Estuaries 8: 182-190

Rasmussen, H. (1989). Oxygen uptake of sediments with special reference to the seasonal variation in Aarhus Bight. M. Sc. thesis, Univ. Aarhus, Denmark

This article was submitted to the editor
Ryther, J. K., Dunstan, W M. (1971). Nitrogen, phosphorus and eutrophication in the coastal marine environment. Science 171. 1008-1013

Seitzinger, S. P. (1988). Denitrification in freshwater and coastal marine ecosystems: ecological and geochemical significance. In: Nixon, S. W (ed.) Comparative ecology of fresh water and coastal marine systems. Limnol. Oceanogr. 33, spec. publ. no. 4: 702-724

Smetacek, V. (1980). Annual cycle of sedimentation in relation to plankton ecology in western Kiel Bight. Ophelia suppl. 1. $65-76$

Smetacek, V. (1985). Role of sinking in diatom life-history cycles: ecological, evolutionary and geological significance. Mar. Biol. 84: 239-251

Solorzano, L. (1969). Determination of ammonia in natural waters by the phenol-hypochlorite method. Limnol. Oceanogr. 14: 799-801

Strickland, J. D., Parsons, T. R. (1972). A practical handbook of seawater analysis, 2nd edn. Bull. Fish. Res. Bd Can. 167

Sundbäck, K., Granéli, W. (1988). Influence of microphytobenthos on the nutrient flux between sediment and water: a laboratory study. Mar. Ecol. Prog. Ser. 43: 63-69

Sundbäck, K., Jönsson, B. (1988). Microphytobenthic productivity and biomass in sublittoral sediments of a stratified bay, southeastern Kattegat. J. exp. mar. Biol. Ecol. 122: $63-81$

Sørensen, J., Jørgensen, B. B. (1987). Early diagenesis in sediments from Danish coastal waters: microbial activity and $\mathrm{Mn}-\mathrm{Fe}-\mathrm{S}$ geochemistry. Geochim. cosmochim. Acta 51: $1583-1590$

Teague, K. G., Madden, C. J., Day, J. W. Jr, (1988). Sedimentwater oxygen and nutrient fluxes in a river-dominated estuary. Estuaries 11. 1-9

Manuscript first received: June 26, 1989

Revised version accepted December 21, 1989 